\title{
Amino acid uptake of Prochlorococcus spp. in surface waters across the South Atlantic Subtropical Front
}

\author{
Mikhail V. Zubkov ${ }^{1, *}$, Glen A. Tarran² \\ ${ }^{1}$ National Oceanography Centre, Southampton, European Way, Southampton SO14 3ZH, UK \\ ${ }^{2}$ Plymouth Marine Laboratory, Prospect Place, Plymouth PL1 3DH, UK
}

\begin{abstract}
To test the hypothesis that surface-living Prochlorococcus spp. (Pro) cyanobacteria metabolism declines towards the boundaries of its natural habitat, a latitudinal transect of surface waters was sampled from the centre of the Southern Atlantic Gyre (SAG, 20 to $35^{\circ} \mathrm{S}$ ) to the South Subtropical Frontal Zone (SSFZ, 35 to $45^{\circ} \mathrm{S}$ ). Along this transect, amino acid uptake rates of Pro, Synechococcus spp. (Syn) and an average bacterioplankton cell were determined using ${ }^{35}$ S-methionine precursor and flow-cytometry sorting, with methionine uptake rate as an index of cellular metabolic activity. Methionine and possibly other amino acids were a very minor nutrient source for Syn, while their contribution to Pro production was significant. Contrary to expectations, the mean methionine uptake rate per Pro cell in the SSFZ was about 3 times higher than in the SAG. The uptake rates per unit Pro biomass were equal to or higher than that of an average bacterioplankton cell in both the SAG and SSFZ. About 20 and $5 \%$ of total bacterioplankton consumption of amino acids could be assigned to Pro in the SAG and SSFZ, respectively. Methionine and leucine turnover rates were 3.5 and 3 times higher in the SSFZ than in the SAG, respectively. These results suggest that Pro remained highly metabolically active and acquired more methionine at its habitat boundaries, despite higher rates of bacterioplankton activity and therefore greater competition, as well as exposure to deep water mixing, low light and low temperature conditions.
\end{abstract}

KEY WORDS: Cyanobacteria · Prochlorococcus · Synechococcus · Bacterioplankton · Flow cyto-metric sorting $\cdot$ Bioassay $\cdot$ Isotopic tracer

Resale or republication not permitted without written consent of the publisher

\section{INTRODUCTION}

The unicellular planktonic cyanobacterial genus Prochlorococcus (Pro) (Chisholm et al. 1988) numerically dominates phytoplankton in the central oceanic gyres (Partensky et al. 1999b), but in boundary areas with higher nutrient concentrations or in oligotrophic regions during periods of deep mixing that entrain deep-water nutrients, the closely related genus Synechococcus (Syn) often dominates (Waterbury et al. 1979, Olson et al. 1990, Moore et al. 1995). However, in many areas the 2 genera coexist throughout the year and the phenomenon of switching between Pro and Syn domination has been observed on numerous occasions (Zubkov et al. 1998, 2000, Partensky et al. 1999a).
Nevertheless, the underlying mechanism responsible for the shift between the different populations remains unclear. In nutrient-poor surface waters, Pro could have a competitive advantage in nutrient uptake over larger Syn because of the former's higher surface areato-volume ratio (Chisholm 1992).

Because it is generally accepted that cyanobacteria are obligate photoautotrophic microorganisms, their photosynthetic activity and inorganic nutrient acquisition, including nitrogen fixation (Zehr et al. 2001), have been extensively studied (Moore et al. 1995, 2002, Lopez-Lozano et al. 2002). Less attention, however, has been paid to their potential heterotrophic activity. It is now known that natural Pro and Syn populations can take up measurable amounts of dissolved organic 
nitrogen in the form of amino acids (Zubkov et al. 2003). The uptake of amino acids as well as other organic nitrogen could provide an additional source of macronutrients to be used in protein synthesis, and make Pro, in particular, photo-organotrophs.

In the present study we determined the amino acid uptake by Pro and Syn in an attempt to find a physiological explanation for the dramatic shift between Proand Syn-dominated surface waters across the South Atlantic Subtropical Front. We hypothesised that surface-living Pro cyanobacteria metabolism based on the specific uptake of methionine declines towards the boundaries of its natural habitat.

\section{MATERIALS AND METHODS}

Sampling site. The study was carried out on board the RRS 'James Clark Ross' (Cruise No. JR91) in September and October 2003. Surface seawater samples were generally collected at 5 to $7 \mathrm{~m}$ depth with a rosette of 201 Niskin bottles mounted on a conductivity-temperature-density (CTD) profiler. Total bacterioplankton and cyanobacteria abundance reported herein were determined at 17 stations (Fig. 1), microbial turnover rates of the amino acids, methionine (met) and leucine (leu) were determined at 13 stations, and group flow-sorting of Pro, Syn and an average bacterioplankton cell preloaded with ${ }^{35} \mathrm{~S}$-methionine were determined at 11 stations.

Bioassay of amino acid concentration and microbial turnover rates using radioactively labelled precursors. To enable quantitative isotopic tracing of their uptake by microorganisms, the initial concentrations of bioavailable amino acids must be known. The ambient concentrations and total microbial and specific cyanobacterial turnover rates of amino acids were estimated using a concentration series bioassay (Wright \& Hobbie 1966) of untreated live samples to avoid the uncertainties of analytical measurements associated with separation of dissolved and particulate pools (Ferguson \& Sunda 1984).

The samples used for rate determinations were initially collected in acid-washed 11 thermos flasks using acid-soaked silicone tubing, and were processed within $1 \mathrm{~h}$ of collection. We used 2 labelled amino acids, ${ }^{35} \mathrm{~S}-$ methionine and ${ }^{3} \mathrm{H}$-leucine (Amersham Biosciences). L$\left[{ }^{35} \mathrm{~S}\right]$ methionine $\left(1000 \mathrm{Ci} \mathrm{mmol}^{-1}\right)$ was added at a standard concentration of $0.13 \mathrm{nM}$ and diluted with non-labelled met using a dilution series of $0.2,0.5,1.0$, 1.5 and $2.0 \mathrm{nM}$. L- $\left[4,5-{ }^{3} \mathrm{H}\right]$ leucine, (specific activity $160 \mathrm{Ci} \mathrm{mmol}^{-1}$ ) was added in a series of $0.1,0.2,0.4,0.6$ and $0.8 \mathrm{nM}$ final concentrations.

Triplicate samples $(1.6 \mathrm{ml})$ for each amino acid addition were incubated in $2 \mathrm{ml}$ capped, screw-top sterile polypropylene microcentrifuge tubes in the dark at in situ temperatures, and 1 each was fixed at 10, 20 and 30 min by adding paraformaldehyde (PFA) to $1 \%$ final concentration. The sample particulate material was harvested onto $0.2 \mu \mathrm{m}$ polycarbonate filters (Poretics) and washed with deionised water (Milli-Q system). Radioactivity retained on the filters was measured as disintegrations $\min ^{-1}(\mathrm{dpm})$ using a liquid scintillation counter (Tri-Carb 3100, Perkin Elmer). The rate of precursor uptake was calculated as the slope of the linear regression of radioactivity against incubation time $\left(\mathrm{r}^{2}>\right.$ 0.93, p < 0.1, n = 3; e.g. Fig. 2a,c) and used to compute an amino acid turnover time by dividing the amount of radioactivity added to a sample by the rate of its uptake per time unit (i.e. day). The resulting turnover times were plotted against a corresponding concentration of added amino acid, and extrapolated using linear regression $\left(r^{2}>0.97, p<0.001, n=5 ;\right.$ e.g. Fig. $\left.2 b, d\right)$. The slope of the regression line gave an estimate of amino acid turnover rate, $V$. The $y$ intercept of the regression line gave an estimate of amino acid turnover time $(t)$, as the sum of the ambient concentration $(S)$ plus the transport constant $\left(K_{T}\right)$ (Wright \& Hobbie 1966), i.e. the $x$ intercept of the regression line:

$$
S+K_{T}=V \times t
$$

where $K_{T}$ is a measure of the affinity of microbial uptake system for an amino acid; the lower the $K_{T}$, the more effective the uptake at low amino acid concentration. To our knowledge there is no artefact-free experimental approach to estimating the $K_{T}$ of natural bacterioplankton. However, as bacterioplankton should be

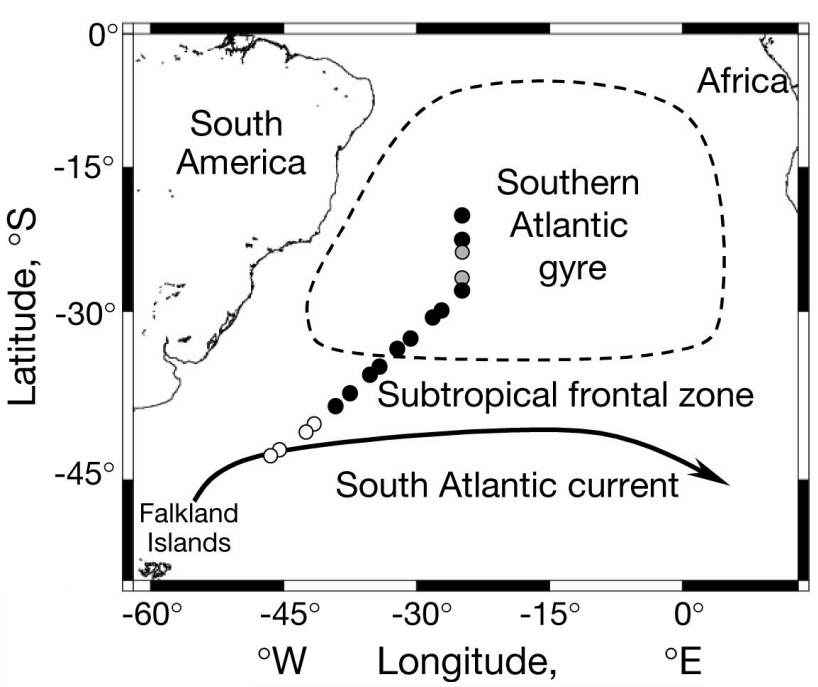

Fig. 1. Areas studied, showing stations (along transect) at which flow-sorting of cyanobacteria was carried out (๑), amino acid uptake rates were estimated $(\bullet, 0)$ and bacterioplankton concentrations $(\bullet, 0,0)$ were determined 

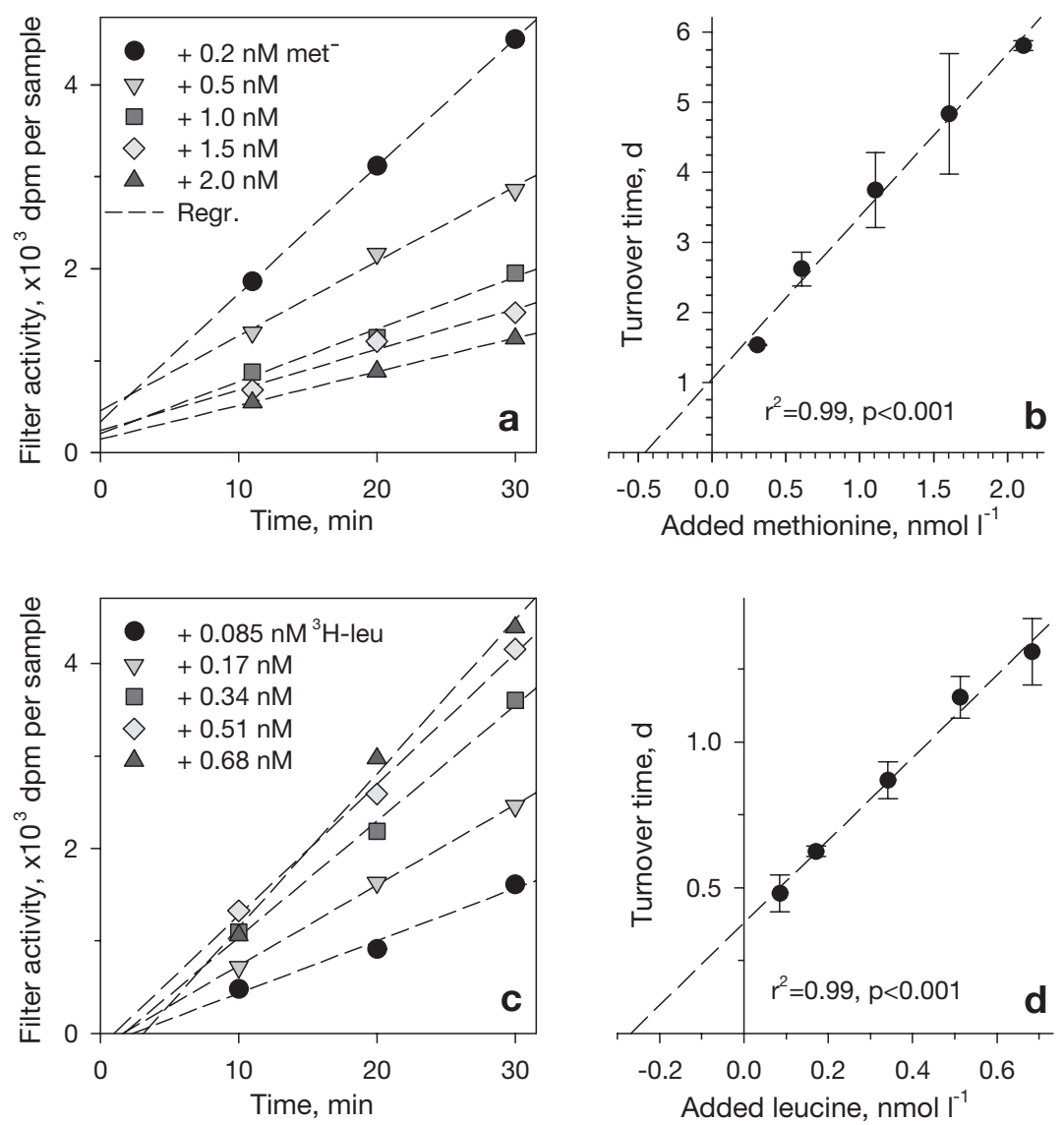

Fig. 2. Bioassay estimation of concentrations and turnover rates of maximum ambient methionine (met) and leucine (leu) in a sample collected at $33.81^{\circ} \mathrm{S}$, $32.07^{\circ} \mathrm{W}$ from a depth of $5 \mathrm{~m}$. (a,c) Time series at different (a) met and (c) leu concentrations with regression lines (Regr.); met uptake was estimated in dilution series in which ${ }^{35} \mathrm{~S}$-met at $0.13 \mathrm{nM}$ was diluted with different amounts of non-labelled met; leu uptake was estimated in a series, in which different amounts of ${ }^{3} \mathrm{H}$-leu were added to samples. (b,d) Relationships between added (b) met and (d) leu concentrations and met or leu pool turnover time; means $\pm 1 \mathrm{SE}$; $y$-axis intercept of regression line is estimate of turnover times at maximum ambient met or leu concentration, which is $x$-axis intercept (details in 'Materials and methods')

well-adapted to living at ambient amino acid concentrations, we hypothesised that their $K_{T}$ would be negligibly small compared to natural concentrations of amino acids $\left(K_{T}<<\mathrm{n} S\right)$. Thus the maximum ambient concentration estimates $\left(S_{\max }=S+K_{T}\right)$ reported herein should be treated as upper estimates.

Flow-cytometry sorting of radioactively labelled bacterioplankton cells. Amino acid uptake by cyanobacteria and other bacterioplankton groups was determined using ${ }^{35} \mathrm{~S}$-methionine (Zubkov et al. 2001) as a representative dissolved free amino acid (DFAA) similar to leu (Kirchman et al. 1985, Zubkov et al. 2003). The uptake of met at the added concentration $(0.84 \pm$ $0.12 \mathrm{nM}$ ) was always within the linear uptake range of the assayed bacterioplankton (e.g. Fig. 2b), and there- fore the uptake rates by Pro and Syn at this concentration were also assumed to be linearly proportional to uptake at ambient concentrations.

We incubated 5 replicated $1.6 \mathrm{ml}$ samples at in situ temperature in the dark, and fixed these with 1\% PFA after $3 \mathrm{~h}$. The samples were then further incubated at $2^{\circ} \mathrm{C}$ for $24 \mathrm{~h}$ and stored frozen at $-80^{\circ} \mathrm{C}$ before being analysed ashore. The long incubation time of $3 \mathrm{~h}$ was chosen for practical reasons only, i.e. to maximise the amount of radiolabel taken up by bacterioplankton cells, since flow-sorting was done 2 mo after sample collection and the ${ }^{35} \mathrm{~S}$ isotope has a relatively short half-life of $87.5 \mathrm{~d}$. The rates of met uptake determined in 30 min time series correlated closely with the rates of met uptake after $3 \mathrm{~h}$ incubation (Pearson correlation coefficient $r=$ 0.974, $\mathrm{p}<0.0001, \mathrm{n}=11$ ). The latter were on average $5 \%$ lower, indicating insignificant substrate limitation during $3 \mathrm{~h}$ incubations, with one $22 \%$ exception at $38.5^{\circ} \mathrm{S}$, where high met uptake rates of $1.25 \mathrm{nM} \mathrm{d}^{-1}$ were combined with a low met concentration of 0.5 nM. Pro and Syn cyanobacteria in thawed samples were enumerated and flow-sorted in unstained samples using their specific chlorophyll/phycoerythrin autofluorescence (Olson et al. 1993).

Syn were only flow-sorted from samples taken within the South Subtropical Frontal Zone (SSFZ) as their abundance in the Southern Atlantic Gyre (SAG) was too low. Abundance of total bacterioplankton was determined with a FACSort flow cytometer (Becton Dickinson) after staining with SYBR Green I DNA dye (Marie et al. 1997), and the abundance of other bacteria (for simplicity referred to below as 'heterotrophic' bacteria) was computed by subtracting cyanobacteria abundance from total bacterial abundance. Yellow-green $0.5 \mu \mathrm{m}$ bead standards (Fluoresbrite Microparticles, Polysciences) were used in all analyses. The FACSort was set at single-cell sorting mode (the highest sorting purity of the instrument) and the target cells were gated and flow-sorted at a rate of 10 to 250 particles $\mathrm{s}^{-1}$. Sorted cells were collected onto $0.2 \mu \mathrm{m}$ pore-size nylon filters and washed with deionised water. Radioactivity retained on the filters was measured as counts $\min ^{-1}$ (cpm) using an 

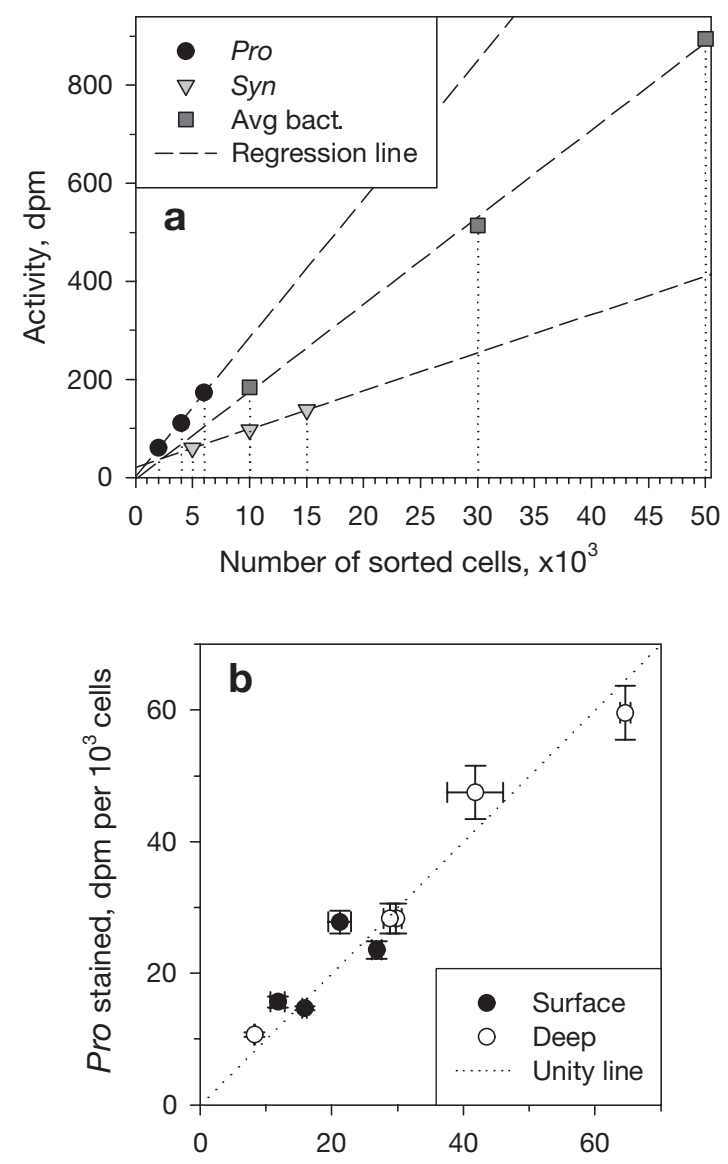

Pro unstained, dpm per $10^{3}$ cells

Fig. 3. Flow-sorting radioassays of cyanobacteria. (a) Assay of surface waters of South Subtropical Frontal Zone collected at $35.62^{\circ} \mathrm{S}, 34.35^{\circ} \mathrm{W}$ from a depth of $6 \mathrm{~m}$, showing ${ }^{35} \mathrm{~S}-\mathrm{met}$ uptake by unstained Prochlorococcus cells (Pro, linear regression coefficient: $r^{2}=0.997$, slope $=28.3 \pm 1.6$ ), Synechococcus cells $\left(\right.$ Syn, $\mathrm{r}^{2}=0.9997$, slope $\left.=7.79 \pm 0.15\right)$, and SYBR Green Istained average bacterial cells (Avg bact., $\mathrm{r}^{2}=0.998$, slope $=$ $17.8 \pm 0.7$ ). (b) Comparison of ${ }^{35} \mathrm{~S}$-met uptake by unstained and stained Pro sorted from surface-water samples collected southwards to $31^{\circ} \mathrm{S}(\bullet)$ and samples collected at depths below $80 \mathrm{~m} \mathrm{(O)}$ in the Southern Atlantic Gyre; means $\pm 1 \mathrm{SE}$

ultra-low level, liquid-scintillation counter (1220 Quantulus) and disintegrations $\mathrm{min}^{-1}(\mathrm{dpm})$ were calculated to correct for radioactive decay. We sorted 3 proportional quantities of the cells (from $0.75,1.5$ and $2.25 \times 10^{3}$ cells to 10,20 and $30 \times 10^{3}$ cells) (Fig. 3a), and mean cellular met uptake was determined as the slope of the linear regression of radioactivity against the number of sorted bacterial cells $\left(\mathrm{r}^{2}>0.98, \mathrm{n}=3\right)$.

Population-specific activity of flow-sorted bacterial groups (e.g. Pro and Syn) was determined by multiplying the radioactivity of the average cell-group sorted by the abundance of the group. The relative population activity was calculated as the population fraction

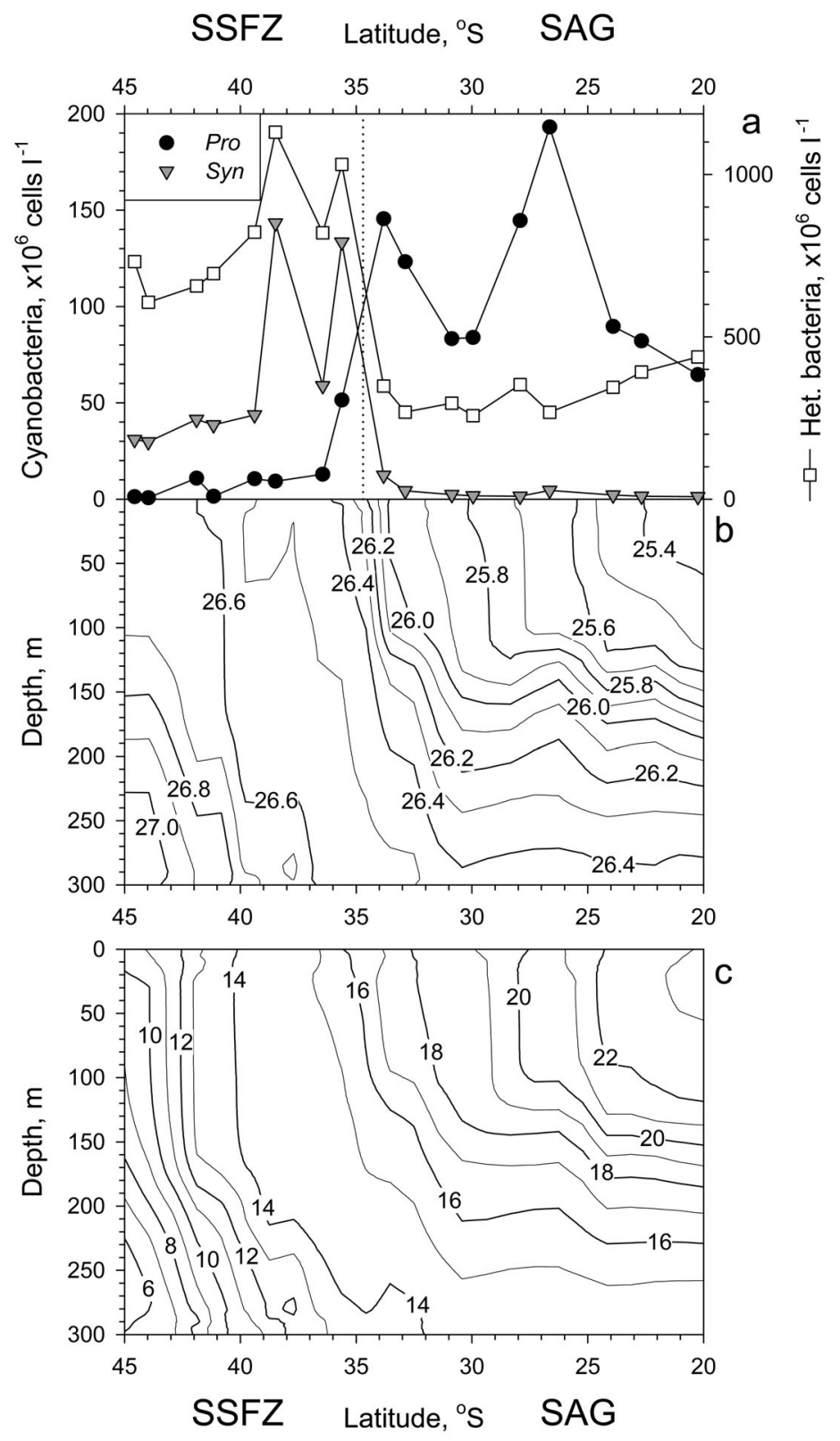

Fig. 4. Southern Atlantic Gyre (SAG) and South Subtropical Frontal Zone (SSFZ) waters, showing (a) latitudinal surface distribution of Prochlorococcus (Pro), Synechococcus (Syn) cyanobacteria and 'heterotrophic' (Het.) bacteria abundance in surface waters (5 to $7 \mathrm{~m}$ ), (b) contour plots of seawater density $\left(\sigma_{t}\right)$ and $(\mathrm{C})$ temperature $\left(T,{ }^{\circ} \mathrm{C}\right)$ in the top $300 \mathrm{~m}$. Vertical dotted line in (a) marks the delineation between water masses

of the total bacterioplankton community. The microbial turnover rates of met, estimated using a concentrationseries bioassay, represented those of the whole bacterioplankton community, i.e. the activity of an average flow-sorted bacterial cell multiplied by the total concentration of bacterioplankton. Hence, we could estimate the flow-sorted population uptake rate of met at 
ambient concentrations by multiplying the microbial turnover rate by the relative population activity. The cell-specific activity was calculated by dividing the absolute population activity by group abundance. The biomass-specific activity was calculated by dividing the cellular activity by mean cellular biomass. Cellular biomass was estimated flow-cytometrically by measuring the arithmetical mean cellular $90^{\circ}$ light-scatter or side-scatter (SSC), determined in logarithmic datacollection mode because of high variability in cell properties, and using standard relative bead units.

Sorting purity was assessed routinely by sorting 1 type of calibration beads (Polysciences) from a mixture of 2 yellow-green bead sizes ( 0.5 and $2 \mu \mathrm{m}$ in diameter) and flow-cytometry reanalysis of the sorted material. The sorted material was $99 \%$ enriched with the target beads. Accuracy of gate-sorting was assessed by comparing the cellular activities of sorted unstained versus SYBR Green I-stained Pro with sufficiently high red fluorescence for clear flow-cytometry separation of the Pro population, i.e. in surface samples collected at latitudes above $31^{\circ} \mathrm{S}$ or at depths below $80 \mathrm{~m}$ (Fig. 3b). Deep-water sample-sortings were done at the time of sorting the surface samples. They were included to increase the data set, to prove the correctness of sorter alignment. The results of deep-water analyses were outside the scope of the present study and have been reported elsewhere (Zubkov et al. 2004).

The compared activities correlated with an almost 1:1 relationship (Pearson correlation coefficient $\mathrm{r}=$ $0.974, \mathrm{p}<0.0001, \mathrm{n}=9$ ), indicating the acceptable accuracy of Pro-sorting (Fig. 3b). At latitudes below $31^{\circ} \mathrm{S}$ it was impossible to reliably separate stained Pro from other bacteria, and therefore we sorted only unstained Pro with red fluorescence clearly above the threshold FACSort levels.

\section{RESULTS AND DISCUSSION}

\section{Physical environment in the study area}

The hypothesis was tested on a transect from $20^{\circ} \mathrm{S}$, $25^{\circ} \mathrm{W}$ to $45^{\circ} \mathrm{S}, 45^{\circ} \mathrm{W}$ across the South Atlantic Ocean (Fig. 1). The SAG waters dominated by Pro (80 to $200 \times$
$10^{6}$ cells $^{-1}$ ) were abruptly replaced within $2^{\circ}$ of latitude $\left(33.8\right.$ to $35.6^{\circ} \mathrm{S}$ ) by the SSFZ (Belkin \& Gordon 1996) waters dominated by Syn (Fig. 4a). The abundance of other bacterioplankton was 2 to 3 times higher in the SSFZ than in the SAG. The transition coincided with sharp changes in seawater density in the traversed front (Fig. 4b). Spatially separated from the seawater density gradient by about $9^{\circ}$, the pronounced latitudinal compression of the isotherms marked the southern end of the SSFZ (Fig. 4c). The SSFZ lacked vertical stratification between the latitudinal compression of isotherm and seawater density contours. The present observations are in good agreement with previous observations made across the front between the Brazil and Falkland currents (Zubkov et al. 2000). Repeated observations in the present study indicated a pronounced Syn-enriched surface-water belt with abundances $>10^{8}$ cells l $^{-1}$, at least around the southern subtropical boundary of the SAG. While Pro abundance was $<10^{7}$ cells $1^{-1}$, species of this genus were still present in the SSFZ, and even at $45^{\circ} \mathrm{S}$ their

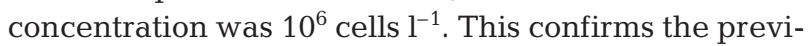
ous record of Pro in comparable concentrations at $47.5^{\circ} \mathrm{S}$ in waters of similar temperature $\left(11^{\circ} \mathrm{C}\right)$ by Zubkov et al. (2000).

\section{Maximum ambient concentration estimates and microbial turnover of methionine and leucine}

The maximum concentrations of met and leu ranged between $0.14-0.57$ and $0.09-0.32 \mathrm{nM}$, respectively (Table 1, Fig. 5a). The maximum concentrations of leu were, on average, about half the met concentrations. The absence of a pronounced latitudinal pattern of change in amino acid concentrations is probably attributable to their transient presence in dissolved form because of their high microbial turnover. The turnover of leu was generally faster than that of met (Table 1, Fig. 5b). Southwards, as far as $35^{\circ} \mathrm{S}$, dissolved met and leu pools were being turned over by microorganisms every 4 and $1.5 \mathrm{~h}$, respectively. In contrast, in the oligotrophic gyre the turnover of met and leu were much slower, the slowest rates being 3 and $1.1 \mathrm{~d}$, respectively. Consequently, the leu turnover rate was 1.4

Table 1. Maximum ambient concentrations and dynamics of dissolved methionine (met) and leucine (leu) in the South Atlantic Gyre (SAG) and South Subtropical Frontal Zone (SSFZ) delineated by latitude $35^{\circ} \mathrm{S}$. All values are means $\pm \mathrm{SD}$

\begin{tabular}{|c|c|c|c|c|c|c|}
\hline \multirow[t]{2}{*}{ Area } & \multicolumn{2}{|c|}{ Concentration (nM) } & \multicolumn{2}{|c|}{ Turnover time (d) } & \multicolumn{2}{|c|}{ Turnover rate $\left(\mathrm{nM} \mathrm{d}^{-1}\right)$} \\
\hline & met & leu & met & leu & met & leu \\
\hline SAG $(n=9)$ & $0.37 \pm 0.13$ & $0.19 \pm 0.08$ & $1.61 \pm 0.64$ & $0.58 \pm 0.28$ & $0.24 \pm 0.08$ & $0.34 \pm 0.14$ \\
\hline $\operatorname{SSFZ}(\mathrm{n}=4)$ & $0.28 \pm 0.16$ & $0.11 \pm 0.03$ & $0.41 \pm 0.22$ & $0.12 \pm 0.06$ & $0.76 \pm 0.37$ & $1.19 \pm 0.52$ \\
\hline
\end{tabular}



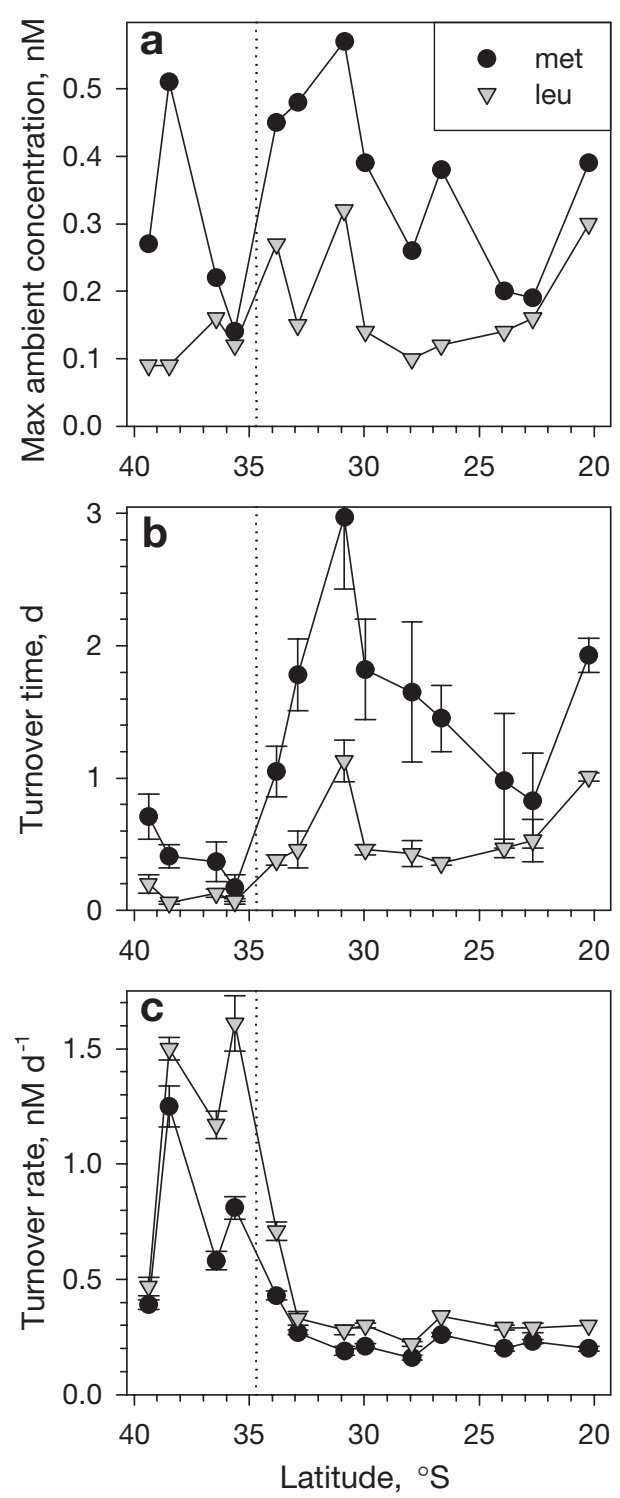

Fig. 5. Comparison of latitudinal surface distributions of maximum ambient concentrations of (a) amino acids, methionine (met) and leucine (leu) and (b) their turnover time. (c) Turnover rates for whole microbial community. Data are means \pm 1 SE for bioassay measurements. Vertical dotted lines mark delineation between water masses

times higher than the met turnover rate in the SAG, and twice as high immediately south of $35^{\circ} \mathrm{S}$. The turnover rates of met and leu showed very similar latitudinal dynamics (Fig. 5c), supporting an earlier conclusion that met constitutes a representative DFAA (Zubkov et al. 2003).

The bioassay technique, although criticised because of the common multiphasic kinetics of a compound's uptake at concentrations significantly higher than ambient (Azam \& Hodson 1981), is still considered applicable if measurements are made at very low added compound concentrations (Williams 1973, Ferguson \& Sunda 1984). Based on our experiments using the technique in the open Atlantic Ocean, a linear relationship is likely (e.g. Fig. 2b,d) when added concentrations are $<1$ to $3 \mathrm{nM}$ and a compound has a rapid turnover time $(<1$ to $3 \mathrm{~d})$ at ambient concentration. However, caution is called for, since the assayed concentration remains an indirect upper or maximum estimate of a sum of the actual ambient concentration plus the transport constant (Wright \& Hobbie 1966). Nevertheless, despite all uncertainties, these maximum estimates are often more realistic than chemical measurements of ultra-low concentrations of microbiologically highly reactive compounds, such as amino acids or sugars.

Previous comparative studies of chemical and microbiological bioassay techniques (e.g. Fuhrman \& Ferguson 1986, Skoog et al. 1999 and references therein) showed close agreement between the estimated amino acid and glucose concentrations in productive coastal waters. Our provisional experiments with ${ }^{3} \mathrm{H}$-thymidine tracer in Southampton Waters showed that it is possible to determine the concentration of added $2 \mathrm{nM}$ thymidine in the presence of ambient thymidine as the difference between the cumulative $2.44 \mathrm{nM}$ in the addition experiment and $0.44 \mathrm{nM}$ in the control without addition (M. V. Zubkov unpubl. data).

\section{Determination of absolute rates of methionine uptake by Pro and Syn cells}

The initial radioactivities of flow-sorted Pro and Syn cells (Fig. 6a) are presented primarily to demonstrate the reproducibility of the measurements made. Fig. 6a illustrates 2 major features: (1) higher uptake of ${ }^{35} \mathrm{~S}$ met by Pro in the SSFZ than in the SAG, suggesting that Pro in the SSFZ were metabolically more active; (2) comparable cellular uptake of Syn in the SSFZ and Pro in the SAG, suggesting that both populations are capable of utilising free amino acids.

By combining the flow-sorting data with the estimated total microbial uptake of met we calculated the cell-specific uptake rate of the Pro and Syn cells (Fig. 6b). After the differences in estimated ambient met concentrations and turnover rates were taken into account, Pro in the SSFZ still had a cell-specific uptake rate 2 to 4 times higher than Pro in the SAG. In addition, the cellular uptake of Syn in the SSFZ and Pro in the SAG remained similar. Using side-scatter as a proxy of cell volume or biomass (Troussellier et al. 1999), the cell-biomass index of Syn was 4 to 6 times higher than that of Pro in the SAG (Fig. 6c), and consequently the biomass-specific activity of Syn was only 

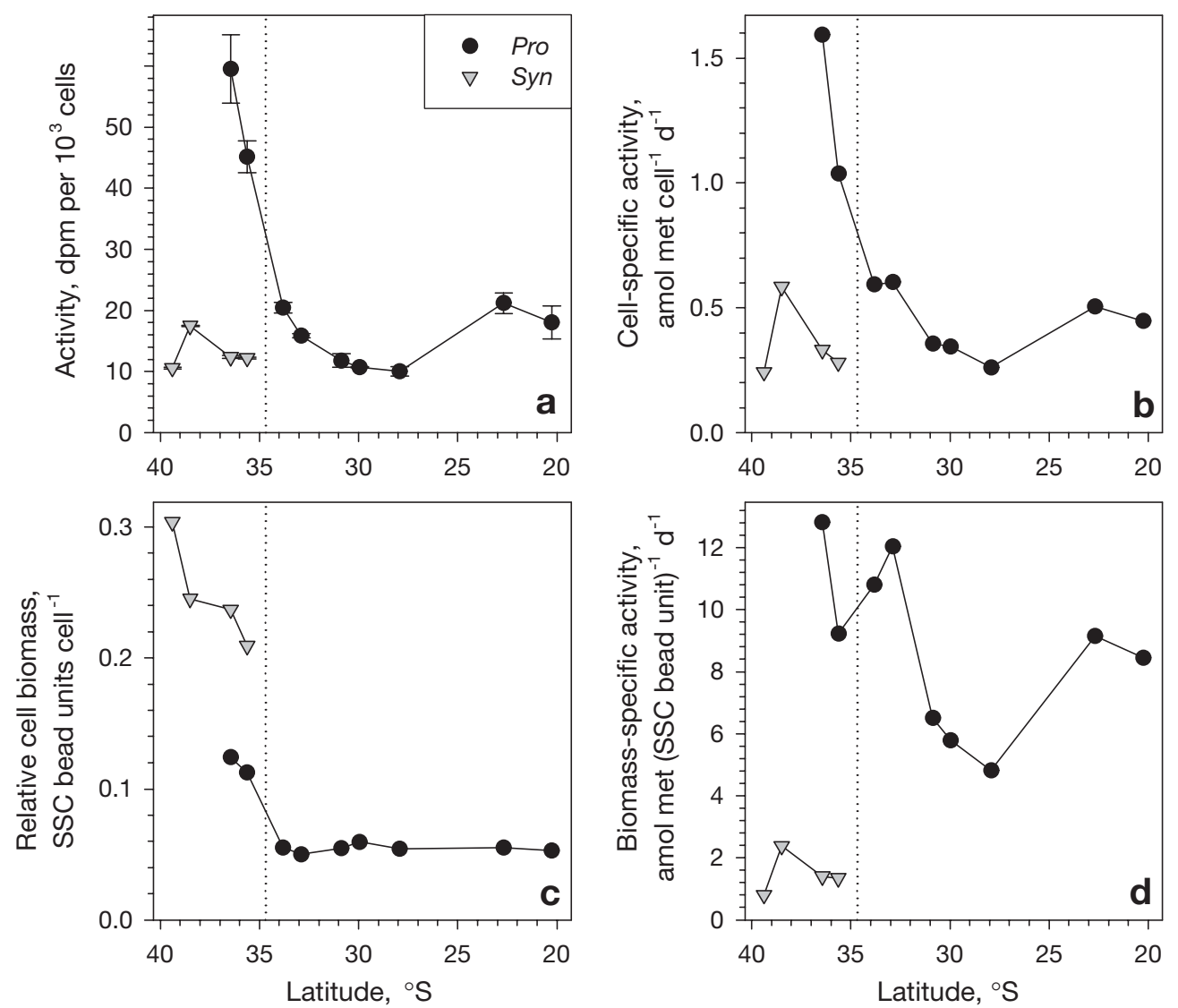

Fig. 6. Prochlorococcus (Pro) and Synechococcus (Syn). Latitudinal surface distributions of (a) uncorrected flow-sorting measurements of methionine (met) uptake rates, (b) absolute estimates of their cell-specific activity, (c) relative estimates of their cellular biomass using side-scatter (SSC) flow-cytometry measurements, and (d) derived biomass-specific activity estimates. In

(a) data are means $\pm 1 \mathrm{SE}(\mathrm{n}=3)$. Vertical dotted lines mark delineation between water masses

about $25 \%$ of that of Pro in the SAG (Fig. 6d). In addition, Pro in the SSFZ had twice the biomass of Pro in the SAG (Fig. 6c), and in fact Pro biomass-specific activities in the SAG and SSFZ were more similar (Fig. 6d) than their cellspecific activities (Fig. 6b).

\section{Comparison of methionine uptake rates by cyanobacteria and total bacterioplankton}

The cell-specific met uptake of Pro cells was $80 \pm 16 \%$ (mean \pm SD) and $200 \pm 53 \%$ of a mean bacterioplankton cell in the SAG and SSFZ, respectively, while the cellular met uptake of the Syn cells in the SSFZ was only $52 \pm$ $8 \%$ (Fig. 7a). The differences between Pro, Syn and total bacterioplankton were even more apparent when their relative biomass-specific met uptake rates were compared (Fig. 7b); the Pro rates were $95 \pm$ 21 and $124 \pm 21 \%$ in the SAG and SSFZ, respectively, while the Syn rates were only $16 \pm 3 \%$ in the SSFZ. At
Table 2. Estimated cellular size (mean $\pm \mathrm{SD}$ ), biomass and methionine uptake (mean \pm SD) by Prochlorococcus spp. (Pro) and Synechococcus spp. (Syn) and average bacterioplankton (Avg bact.) in SAG and SSFZ. Cellular diameter taken from a previous study of Pro in the same region (Zubkov et al. 2000), and estimated using size-fractionation method. A factor of $0.2 \mathrm{pg} \mathrm{C} \mathrm{mm}^{-3}$ was used to convert cell volume to cell carbon content, and carbon and protein cellular contents were assumed to be equal (Simon \& Azam 1989). Number of independent measurements made is indicated in parentheses. nd: no data

\begin{tabular}{|lcccc|}
\hline $\begin{array}{l}\text { Area, } \\
\text { cell type }\end{array}$ & $\begin{array}{c}\text { Diameter } \\
(\mu \mathrm{m})\end{array}$ & $\begin{array}{c}\text { Biomass } \\
(\mathrm{fg} \text { protein) }\end{array}$ & $\begin{array}{c}\text { Methionine uptake } \\
\text { amol cell } \mathrm{d}^{-1} \% \text { cell protein } \mathrm{d}^{-1}\end{array}$ \\
\hline SAG & & & & \\
Avg bact. & $0.47 \pm 0.02(4)$ & 11 & $0.56 \pm 0.15(7)$ & 0.76 \\
Pro & $0.54 \pm 0.03(4)$ & 16 & $0.44 \pm 0.13(7)$ & 0.41 \\
Syn & $1.1 \pm 0.19(4)$ & 140 & nd & - \\
SSFZ & & & & 1.1 \\
Avg bact. & $0.45 \pm 0.02(4)$ & 9 & $0.68 \pm 0.20(4)$ & 0.73 \\
Pro & $0.63 \pm 0.04(4)$ & 27 & $1.3 \pm 0.39(2)$ & 0.054 \\
Syn & $0.98 \pm 0.08(4)$ & 99 & $0.36 \pm 0.15(4)$ & \\
\hline
\end{tabular}


the cyanobacterial population level, Pro contributed $19 \pm 6$ and $5 \pm 2 \%$ to the total bacterioplankton uptake of met in the SAG and SSFZ, respectively, and Syn contributed $4 \pm 3 \%$ in the SSFZ (Fig. 7c). For comparison, Pro comprised $24 \pm 7$ and $3 \pm 2 \%$ of the total bacterioplankton abundance in the SAG and SSFZ, respectively, while Syn comprised $8 \pm 3 \%$ in the SSFZ and $<1 \%$ in the SAG (Fig. $7 \mathrm{~d}$ ).

The $20 \%$ Pro population contribution to the total bacterioplankton met uptake in the SAG is significant but lower than the $33 \%$ Pro contribution in the oligotrophic but more productive waters of the Arabian Sea (Zubkov et al. 2003), corroborating that met uptake by Pro is a general characteristic of this genus. The similar contributions of Syn in the SSFZ of the Atlantic Ocean and Arabian Sea were remarkably consistent, giving greater confidence in the methodology used.

To evaluate how important met is to Pro and Syn compared to other bacterioplankton, we estimated how much the uptake of met could contribute to their biomass (Table 2). The amount of met taken up by a mean Pro cell was estimated to contribute about 0.4 and $0.7 \% \mathrm{~d}^{-1}$ to Pro cellular biomass in the SAG and
SSFZ, respectively. Therefore, a single dissolved amino acid at an ambient concentration 0.1 to $0.5 \mathrm{nM}$ is a measurable and (compared to the average bacterioplankton cell) relatively important source of organic nitrogen for Pro. If we speculate further that other amino acids could be taken up at comparable rates to leu (Table 1, Fig. 5) and tyrosine (M. V. Zubkov unpubl. data from same cruise), the data suggest that the combined contribution of even 3 amino acids to the Pro diet could rise to about $2 \% \mathrm{~d}^{-1}$. Considering that only a fraction of Pro cells divide every day and that there are other dissolved amino acids that could be consumed by Pro, the contribution of amino acids to Pro production may be significant. In contrast, it is evident that methionine and possibly other amino acids are a very minor nutrient source for Syn.

\section{CONCLUSIONS}

From the results of this study it is clear that the hypothesis 'surface-living Prochlorococcus cyanobacteria metabolism based on cellular met uptake declines
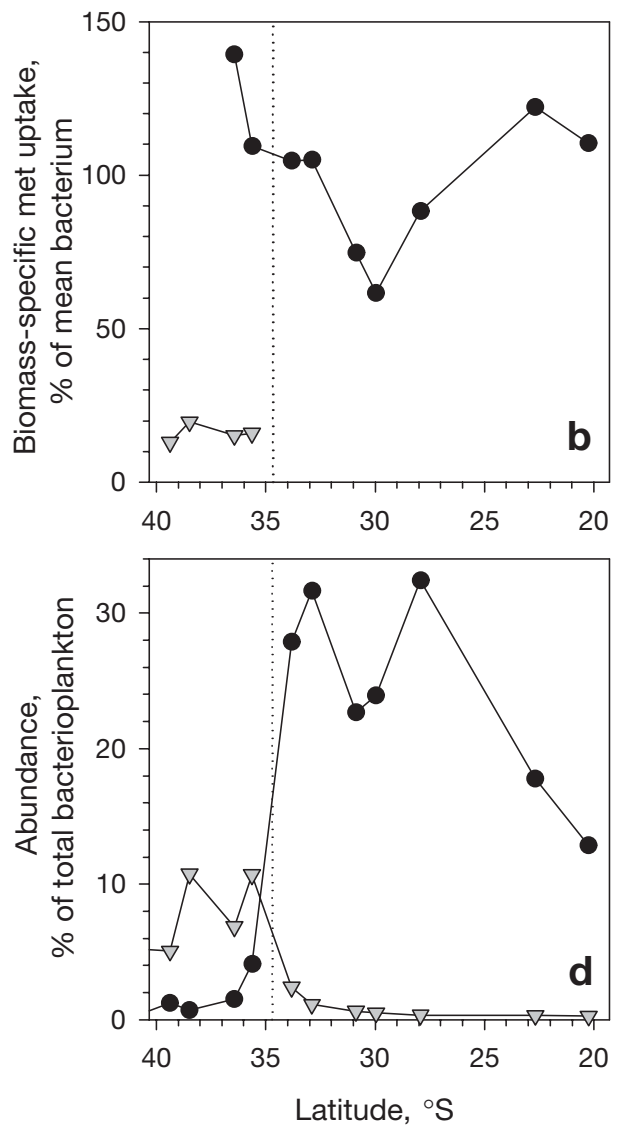

Fig. 7. Prochlorococcus (Pro) and Synechococcus (Syn). Latitudinal surface distribution of (a) cell-, (b) biomass- and (c) populationspecific uptake rates of methionine (met); (d) cyanobacteria abundance relative to an average cell or total population of bacterioplankton. Vertical dotted lines mark delineation between water masses 
towards the boundaries of its natural habitat', should be rejected, as Pro amino acid uptake in the surface waters of the SSFZ (the southern limit of its distribution) was significantly higher than in the SAG. Despite their high rates of amino acid uptake, Pro numbers dwindled in the SSFZ. The increased turnover of amino acids by other microorganisms could be a competitive factor leading to a Pro decline.

Acknowledgements. We acknowledge the captain, officers, crew and fellow scientists aboard RRS 'James Clark Ross' for their support during Cruise JR91. This work forms a part of the Atlantic Meridional Transect Consortium Programme (NER/O/S/2001/00680) and was funded by the Natural Environment Research Council (NERC), UK, Plymouth Marine Laboratory Core Programme. The research of M.V.Z. was supported by an NERC advanced research fellowship (NER/I/S/2000/00898). In addition, we thank the anonymous reviewer of this paper for insightful criticism. This is contribution number 99 of the AMT programme.

\section{LITERATURE CITED}

Azam F, Hodson RE (1981) Multiphasic kinetics for D-glucose uptake by assemblages of natural marine bacteria. Mar Ecol Prog Ser 6:213-222

Belkin IM, Gordon AL (1996) Southern Ocean fronts from the Greenwich meridian to Tasmania. J Geophys Res C 101: 3675-3696

Chisholm SW (1992) Phytoplankton size. In: Falkowski PG, Woodhead AD (eds) Primary productivity and biogeochemical cycles in the sea. Plenum Press, New York, p 213-237

Chisholm SW, Olson RJ, Zettler ER, Goericke R, Waterbury JB, Welschmeyer NA (1988) A novel free-living prochlorophyte abundant in the oceanic euphotic zone. Nature 334: 340-343

Ferguson RL, Sunda WG (1984) Utilization of amino-acids by planktonic marine-bacteria -importance of clean technique and low substrate additions. Limnol Oceanogr 29:258-274

Fuhrman JA, Ferguson RL (1986) Nanomolar concentrations and rapid turnover of dissolved free amino-acids in seawater-agreement between chemical and microbiological measurements. Mar Ecol Prog Ser 33:237-242

Kirchman D, Knees E, Hodson R (1985) Leucine incorporation and its potential as a measure of protein-synthesis by bacteria in natural aquatic systems. Appl Environ Microbiol 49:599-607

Lopez-Lozano A, Diez J, El Alaoui S, Moreno-Vivian C, Garcia-Fernandez JM (2002) Nitrate is reduced by heterotrophic bacteria but not transferred to Prochlorococcus in non-axenic cultures. FEMS Microbiol Ecol 41:151-160

Marie D, Partensky F, Jacquet S, Vaulot D (1997) Enumeration and cell cycle analysis of natural populations of marine picoplankton by flow cytometry using the nucleic acid stain SYBR Green I. Appl Environ Microbiol 63: 186-193

Moore LR, Goericke R, Chisholm SW (1995) Comparative physiology of Synechococcus and Prochlorococcus: influence of light and temperature on growth, pigments, fluorescence and absorptive properties. Mar Ecol Prog Ser

Editorial responsibility: William K. W. Li,

Dartmouth, Nova Scotia, Canada
116:259-275

Moore LR, Post AF, Rocap G, Chisholm SW (2002) Utilization of different nitrogen sources by the marine cyanobacteria Prochlorococcus and Synechococcus. Limnol Oceanogr 47:989-996

Olson RJ, Chisholm SW, Zettler ER, Altabet MA, Dusenberry JA (1990) Spatial and temporal distributions of prochlorophyte picoplankton in the North Atlantic Ocean. DeepSea Res 37:1033-1051

Olson RJ, Zettler ER, DuRand MD (1993) Phytoplankton analysis using flow cytometry. In: Kemp PF, Sherr BF, Sherr EB, Cole JJ (eds) Handbook of methods in aquatic microbial ecology. Lewis Publishers, Boca Raton, FL, p 175-186

Partensky F, Blanchot J, Vaulot D (1999a) Differential distribution and ecology of Prochlorococcus and Synechococcus in oceanic waters: a review. Bull Inst Océanogr 19: $457-475$

Partensky F, Hess WR, Vaulot D (1999b) Prochlorococcus, a marine photosynthetic prokaryote of global significance. Microbiol Mol Biol Rev 63:106-127

Simon M, Azam F (1989) Protein content and protein synthesis rates of planktonic marine bacteria. Mar Ecol Prog Ser 51:201-213

Skoog A, Biddanda B, Benner R (1999) Bacterial utilization of dissolved glucose in the upper water column of the Gulf of Mexico. Limnol Oceanogr 44:1625-1633

Troussellier M, Courties C, Lebaron P, Servais P (1999) Flow cytometric discrimination of bacterial populations in seawater based on SYTO 13 staining of nucleic acids. FEMS Microbiol Ecol 29:319-330

Waterbury JB, Watson SW, Guillard RRL, Brand LE (1979) Wide-spread occurence of a unicellular, marine planktonic, cyanobacterium. Nature 277:293-294

Williams PJL (1973) The validity of application of simple kinetic analysis to heterogeneous microbial populations. Limnol Oceanogr 18:159-165

Wright RT, Hobbie JE (1966) Use of glucose and acetate by bacteria and algae in aquatic ecosystems. Ecology 47: 447-464

Zehr JP, Waterbury JB, Turner PJ, Montoya JP, Omoregie E, Steward GF, Hansen A, Karl DM (2001) Unicellular cyanobacteria fix $\mathrm{N}-2$ in the subtropical North Pacific Ocean. Nature 412:635-638

Zubkov MV, Sleigh MA, Tarran GA, Burkill PH, Leakey RJG (1998) Picoplanktonic community structure on an Atlantic transect from 50 degrees $\mathrm{N}$ to 50 degrees $\mathrm{S}$. Deep-Sea Res I 45:1339-1355

Zubkov MV, Sleigh MA, Burkill PH, Leakey RJG (2000) Picoplankton community structure on the Atlantic Meridional Transect: a comparison between seasons. Prog Oceanogr 45:369-386

Zubkov MV, Fuchs BM, Burkill PH, Amann R (2001) Comparison of cellular and biomass specific activities of dominant bacterioplankton groups in stratified waters of the Celtic Sea. Appl Environ Microbiol 67:5210-5218

Zubkov MV, Fuchs BM, Tarran GA, Burkill PH, Amann R (2003) High rate of uptake of organic nitrogen compounds by Prochlorococcus cyanobacteria as a key to their dominance in oligotrophic oceanic waters. Appl Environ Microbiol 69:1299-1304

Zubkov MV, Tarran GA, Fuchs BM (2004) Depth related amino acid uptake by Prochlorococcus cyanobacteria in the Southern Atlantic tropical gyre. FEMS Microbiol Ecol 50:153-161

Submitted: October 18, 2004; Accepted: April 12, 2005

Proofs received from author(s): September 9, 2005 